\title{
Bipolar Plates Injection Molded for Series Production
}

ISSN: 2576-8840

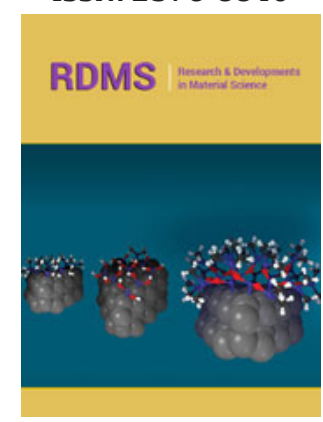

*Corresponding author: Hickmann T, Eisenhuth GmbH \& Co. KG, Friedrich-EbertStraße 2013, 37520 Osterode, Germany

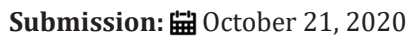

Published: 制 November 11, 2020

Volume 14 - Issue 3

How to cite this article: Hickmann T. Bipolar Plates Injection Molded for Series Production. Res Dev Material Sci. 14(3). RDMS.000836. 2020. DOI: $10.31031 /$ RDMS.2020.14.000836

Copyright@ Hickmann T. This article is distributed under the terms of the Creative Commons Attribution 4.0 International License, which permits unrestricted use and redistribution provided that the original author and source are credited.

\author{
Hickmann $\mathrm{T}^{1 *}$ \\ ${ }^{1}$ Eisenhuth GmbH \& Co. KG, Germany
}

\section{Opinion}

The discussion of renewable energy goes on, and Fuel cells come more and more an important issue in this renweable world. Fuel cells are basically galvanic cells converting chemical energy directly into electrical energy. Depending on the specific technology, this reaction may take place at elevated temperatures, thus technical requirements for materials and components of the stack become more and more challenging.

However, the production of graphitic bipolar plates is quite challenging. When it comes to the processability of highly filled plastic compounds, a compromise must be found between good flowability on the one hand and special properties such as electrical conductivity on the other hand. A common way to develop novel material solutions for polymer composites characterized by high thermal and / or electrical conductivity is the use of conductive graphite up to 80-85 wt.\% filler content in composites for Graphite or Titanium or Nickelpowder. Such highly filled graphite-thermoplastic composites can be used as bipolar plates in fuel cells or as plates in electrolyzers [1-3].

The suitable compounds are an essential starting material in electrochemical applications. These are plastics which are highly filled with graphite and carbon black and thus exhibit electrically and thermally conductive properties. In the case of the thermoplast method a thermoplastic binder with a defined degree of polymerization is compounded with the graphite material. The chemical structure of the polymer remains unchanged during compounding or moulding process. The polymer has to be selected with sufficient chemical and thermal stability (e.g. data from [4]. Several material candidates are available on the market in high quality and well defined configurations.

Different options for usage are possible, such as material for heat exchanger. And the gaphite compounds are also reliable materials for bipolar plates for fuel cells or Redox Flow Batteries. The compounds meet the special requirements with regard to corrosion resistance (partly with coating), availability and resource efficiency [5].

In order to find out which formulation of the materials is suitable for Fuel cell applications, several test series were carried out. For this reason, Eisenhuth has used 2 standard tools that it has developed itself: On the one hand a "spiral tool“ and on the other hand a test "pull rod“ tool. With the spiral tool it can be determined how the flowability is suitable. The spiral tool is a suitable means of determining the flowability, after all, the length of the spiral makes it possible to make a statement about flow length in the series tool. Especially with this tool a comparison of the different compounds can be made.

This knowledge must now be transferred to the series mould. The focus of the consideration is a tool for bipolar plates, i.e. the electrically conductive components required to build a fuel cell stack. For the process it is necessary to use a big injection moulding machine. In this case, the trials were operated on a Krauss-Maffei injection moulding machine with a clamping force of $1700 \mathrm{t}$ (Figure 1). However, in view of the explosive increase in production quantities, it is not enough to manufacture just a simple tool. Rather, multiple moulds, such as the 4-cavity mould shown here, are the means of choice. And the multiple mould also causes the difficulties when designing the mould. 


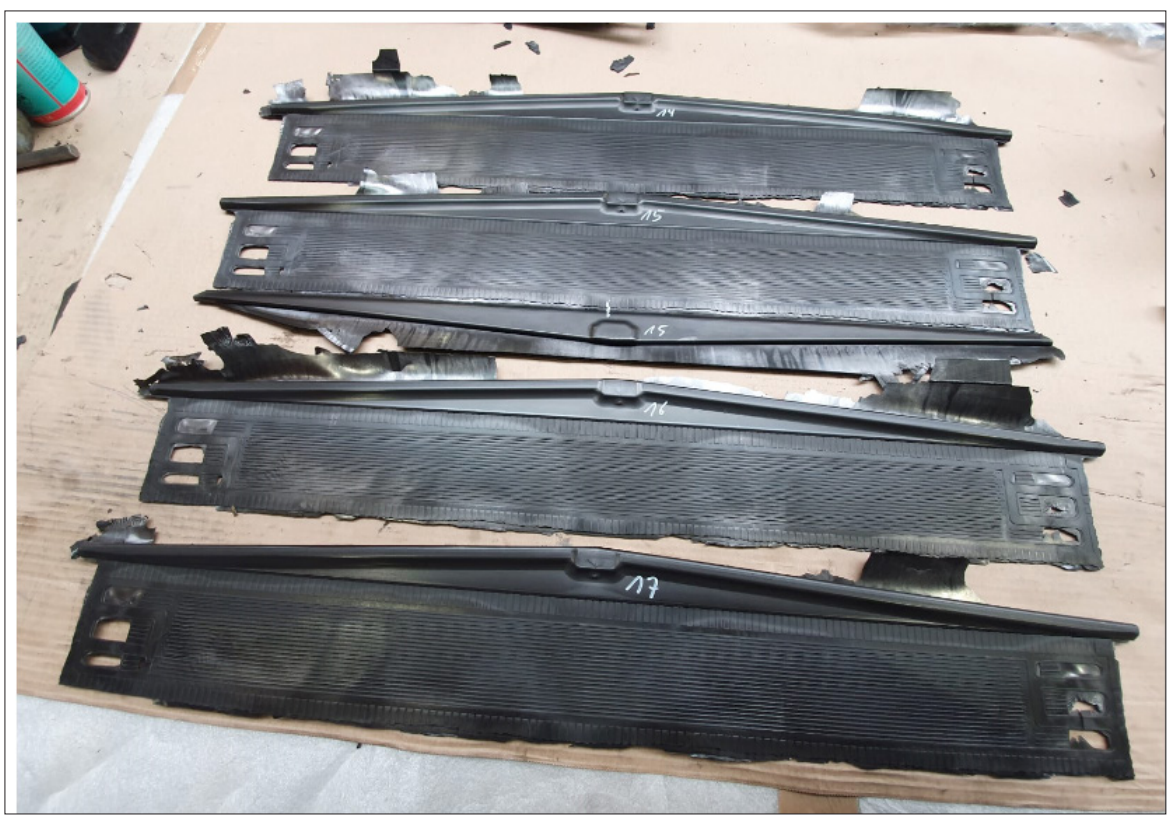

Figure 1: View of mould in a $1700 \mathrm{t}$ injection moulding machine: set up control of mould.

The following applies to the 4-cavity mould: The precise manufacture of bipolar plates from highly filled graphite compounds has so far posed a major technical challenge, especially for fuel cells. Due to the high injection pressures and short flow paths of the compound melt required for the injection moulding process, the production of larger bipolar plates is currently extremely difficult. This makes it all the more important to examine the process in detail: starting with the design, the simulation carried out, the production of the mould and finally the injection moulding process itself (Figure 2). The German government has identified fuel cells and hydrogen as a central field of action. The focus here is on the development and optimisation of fuel cells for mobile applications such as passenger cars, but also trucks and buses. Energy-efficient production of the high-quality components of these technologies is at least as important.

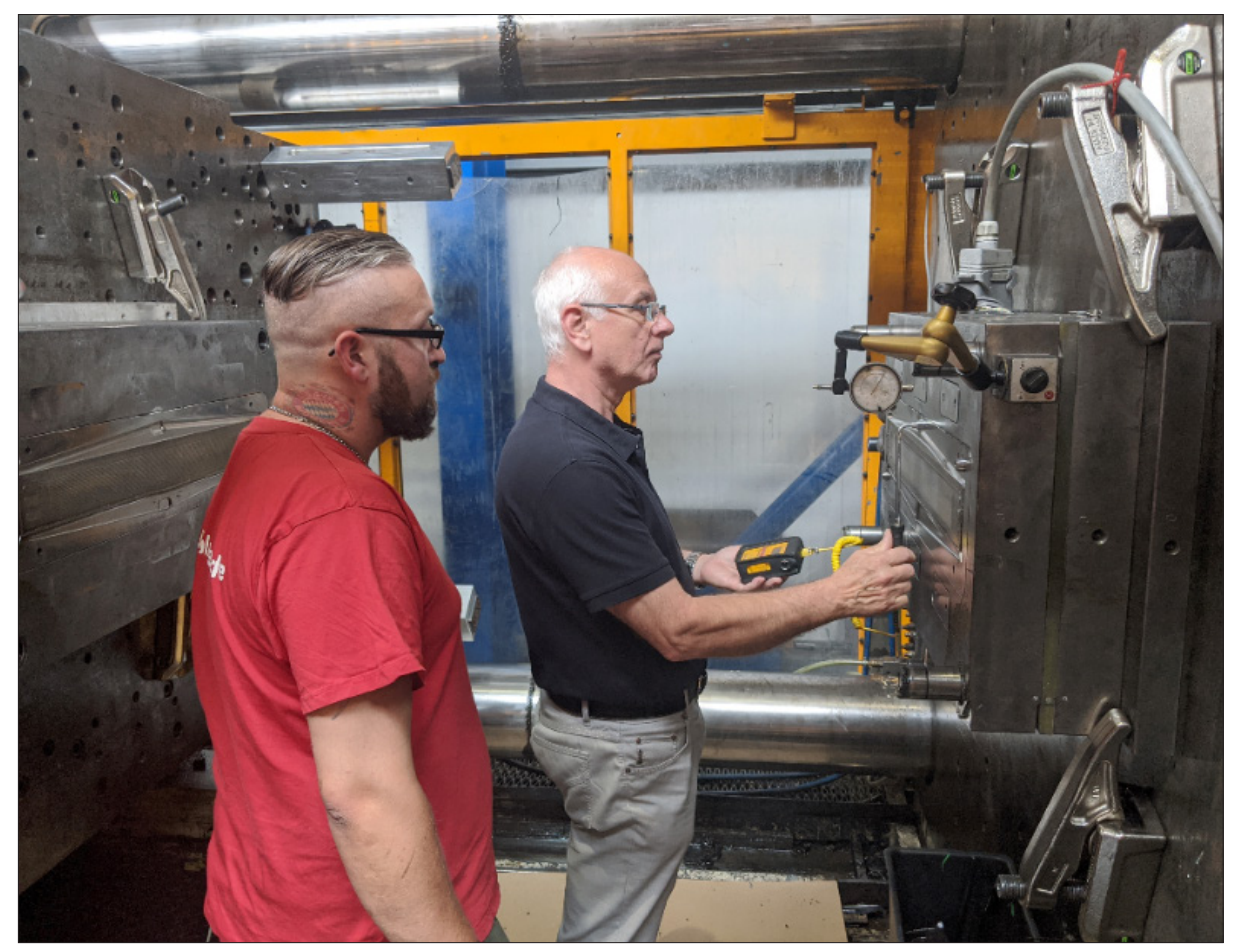

Figure 2: Parts out of 4-cavity mould for injection of a bipolar plate. 
The project is funded by the Federal Ministry of Transport and Digital Infrastructure under the funding code 03BI1 008A2, for which the project partners would like to thank them.

\section{References}

1. Apelt S, Hickmann T, Marek A, Widdecke H (2006) Wie leitfähige Compounds wirken. In Kunststoffe, pp. 86-90

2. Larminie J, Dicks A (2000) Fuel cell systems explained. Wiley, New York, USA.
3. Sievers GW, Anklam K, Henkel R, Hickmann T, Brueser V (2019) Corrosion-protection of moulded graphite conductive plastic bipolar plates in PEM electrolysis by plasma processing. International Journal of Hydrogen Energy.

4. Bonnet M (2013) Kunststofftechnik, Springer Verlag, Hamburg, Germany.

5. Hickmann T (2008) Kunststoffe in der PEM Brennstoffzelle - plastic applications in PEM fuel cells in VDI Berichte. Pp. 81-83.

For possible submissions Click below: 